\title{
Relapses and Recurrent Chronic Bacteric Prostatitis - Biofilm Related, A Case Report
}

\author{
Luisetto $\mathbf{M}^{* 1}$, Behzad Nili-Ahmadabad ${ }^{2}$ and Ghulam Rasool Mashori ${ }^{3}$ \\ ${ }^{1}$ Applied Pharmacologist, European Specialist in lab Medicine, Italy \\ ${ }^{2}$ Pharm D/PhD innovative Pharmaceutical product development specialist, USA \\ ${ }^{3}$ Department of Medical \& Health Sciences for Woman, Peoples University of Medical and Health Sciences for Women, Pakistan
}

Submission: December 01, 2017; Published: December 11, 2017

*Corresponding author: Luisetto M, Applied Pharmacologist, European Specialist in lab Medicine, Independent Researcher, Italy, Email: maurolu65@gmail.com.

Keywords: Chronic Prostatitis; Relapses; Recurrent Uti; Biofilm ;Antimicrobial Therapy

\section{Introduction}

This case report we like to introduce the problem involved in relapses in chronic bacterial prostatitis Under also a specific clinical pharmacist and medicinal chemistry approach [14]. We describe a single case related to patient XY, 50 years old, male, diabetic tipe II, with a long time chronic prostatic disease often treated in the same way:Using oral antimicrobials (fluorochinolons, macrolides, and other) finasteride, serenoa, fans, local steroid but with systematic relapses. After antimicrobial treatment improve urinary fluss. (functional) Psa in normal level, cultures negatives, pathologic fluxometria, negative citologic test.

a) First Transrectal ecografy results: according flogosis and microcalcifications.

b) Drug posology used: fluorochinolons, macrolides in normal dosage Cicle 7-12 days long.

c) Usual time to relapse: 1-3 mouth. After 3 days of therapy improved simptoms.

d) Specialist consulting: the same therapy: antimicorbials, local fans, finasteride, serenoa repens, cortisons, bromeline, tamsulosine.

e) Also emergency acces: the same kind of therapy but prolonged time 12 day fluorochinolons .

But also in this cases relapses. To adeguately observe this case we think is interesting observe what reported in literature [8-15]:

\section{From Literature We Hav Find That}

According Vittorio Magri "Combined administration of azithromycin (1500 mg week-1) with ciprofloxacin at the rate of $750 \mathrm{mg}$ day- 1 for 4 weeks rather than at $500 \mathrm{mg}$ day- 1 for 6 weeks increased the eradication rates from $62.35 \%$ to $77.32 \%$ and the total bacteriological success from $71.76 \%$ to $85.57 \%$. A significant decrease in pain and voiding signs/symptoms and a significant reduction in inflammatory leukocyte counts and serum prostate-specific antigen (PSA) were sustained throughout an 18-month follow-up period in both groups. Ejaculatory pain, haemospermia and premature ejaculation were significantly attenuated on microbiological eradication in both groups, but the latter subsided more promptly in the Cipro-750 cohort. In total, 59 Cipro-750 patients showed mild-to-severe erectile dysfunction (ED) at baseline, while 22 patients had no ED on microbiological eradication and throughout the followup period. In conclusion fluoroquinolone-macrolide therapy resulted in pathogen eradication and CBP symptom attenuation, including pain, voiding disturbances and sexual dysfunction. A once-daily 750-mg dose of ciprofloxacin for 4 weeks showed enhanced eradication rates and lower inflammatory white blood cell counts compared to the 500-mg dose for 6 weeks. Our results are open to further prospective validation.

Relapse due to incomplete pathogen eradication is also likely to occur because of the transition of planktonic bacteria to sessile, chemoresistant, quorum sensing-activated biofilms [13-15]. For these reasons, current pharmacological research in the field of bacterial prostatitis also focuses on the investigation of new prostatotropic antibacterials or on the optimisation of dosages and combinations of available antibiotics $[16,17]$. Fluorochinolone a spettro allargato (solitamente ciprofloxacina), cui viene associato un macrolide (solitamente azitromicina) (Magri $V$ et al. [16]) L'associazione di quest'ultimo al fluorochinolone è considerata particolarmente favorevole; 
dati di letteratura mostrano che i macrolidi sono caratterizzati da una buona penetrazione a livello prostatico (Wagenlehner FM [17]) da una spiccata attività nei confronti dei batteri gram-positivi, di micoplasmi e di Chlamydia, e dalla capacità di inibire la formazione dei biofilm, costituiti da colonie batteriche annidate all'interno di matrici polisaccaridiche. La persistenza dei biofilm batterici a livello prostatico, e la loro resistenza a concentrazioni battericide di antibiotici, è ritenuta essere la principale causa delle recidive e delle persistenze nelle prostatiti di tipo II. I macrolidi sono stati recentemente suggeriti da esperti internazionali quali antibiotici da impiegarsi per il trattamento delle prostatiti croniche batteriche (Wagenlehner [17]).

\section{Takeshi Mikuniya et al. [6] Writed That}

"Foreign body-associated infectious disease is currently one of the most problematic hospital-acquired infections. Patients with placement of urinary catheters are especially susceptible to such infection, that is biofilm infection. In this study, we focused on the therapeutic efficacy of prulifloxacin (PUFX) against Pseudomonas aeruginosa OP 14-210, isolated from a patient with complicated urinary tract infection. This microbe formed a biofilm on the surface of a polyethylene tube (PT) placed in a rat bladder without surgical manipulation. In addition, we attempted to eradicate the biofilm by treatment with a combination of PUFX and fosfomycin (FOM). A single oral administration of PUFX at a dose of $20 \mathrm{mg} / \mathrm{kg}$ was effective against $P$. aeruginosa as a biofilm, yielding a significant reduction in CFU per PT of approximately $1 \log 10$ CFU/PT compared with that in untreated controls. A similar therapeutic effect was also observed in levofloxacin-treated rats, and albeit slightly weaker, in ciprofloxacin-treated animals as well. Because 3 days' consecutive treatment with each fluoroquinolone did not further decrease the viable cell counts on the PT, we tested the efficacy of combining PUFX and FOM. These two drugs, administered once a day for 3 days, at doses of 20 and $100 \mathrm{mg} /$ $\mathrm{kg}$, respectively, resulted in significant decreases of viable cell counts on the PT of more than $1.5 \log 10 \mathrm{CFU} / \mathrm{PT}$ compared with PUFX alone $(\mathrm{P}<0.05)$. As seen by scanning electron microscopy, destruction and disappearance of multilayer biofilms occurred after treatment with this drug combination. Such combination therapy with PUFX and FOM may be advantageous for treating biofilm-related infectious diseases"[6].

And Cristina Delcaru et al. [7] showed that "The effectiveness of antibiotics belonging to different classes to penetrate biofilm matrix varies. For example, cationic aminoglycosides are trapped by the negatively charged polymers of the biofilm matrix, the beta-lactams, and glycopeptides diffusion is reduced, while the fluoroquinolones and rifampicin penetrate immediately, explaining the rapid installation of the bactericidal effect (19 min) [69], as well as macrolides [70]. The most efficient antibiofilm combinations cited in the literature are clarithromycin plus vancomycin, and roxithromycin plus imipenem [36]. To reduce the side effects of antibiotics, co-administration of probiotics is necessary to restore intestinal homeostasis after prolonged treatment with antibiotics or immunological imbalances, which is achieved by reducing the production of pro-inflammatory cytokines and the prevention of epithelial cells apoptosis [7] (Figures 1-3).
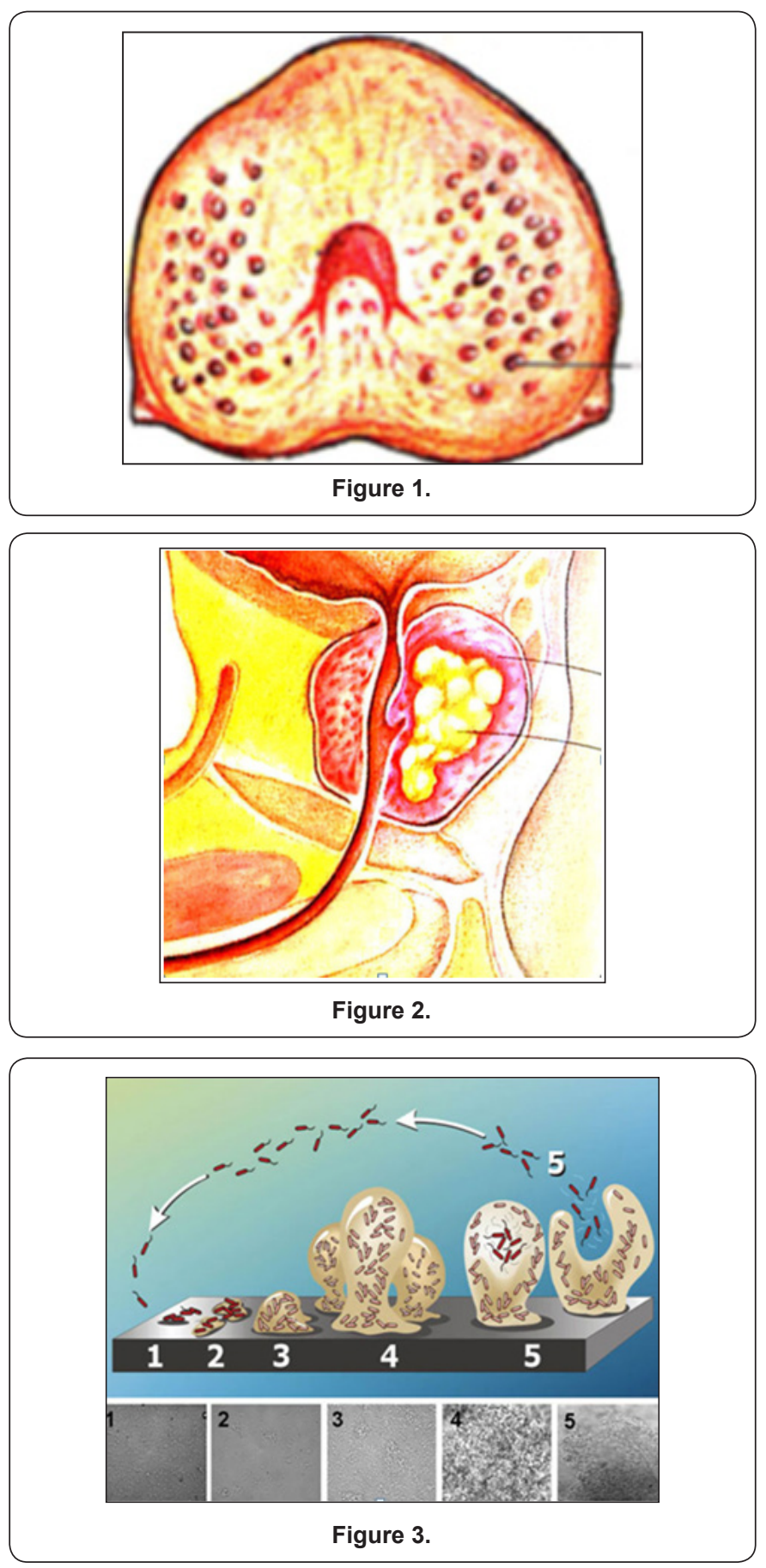

Bjerklund Johansen TE et al. [8] writed that

"The minimum duration of antibiotic treatment should be 2-4 weeks. If there is no improvement in symptoms, treatment should be stopped and reconsidered. However, if there is improvement, it should be continued for at least a further 2-4 weeks to achieve clinical cure and, hopefully, eradication of the 
causative pathogen. Antibiotic treatment should not be given for 6-8 weeks without an appraisal of its effectiveness. Currently used antibiotics are reviewed. Of these, the fluoroquinolones ofloxacin and ciprofloxacin are recommended because of their favourable antibacterial spectrum and pharmacokinetic profile"[8] (Figures 4 \& 5).

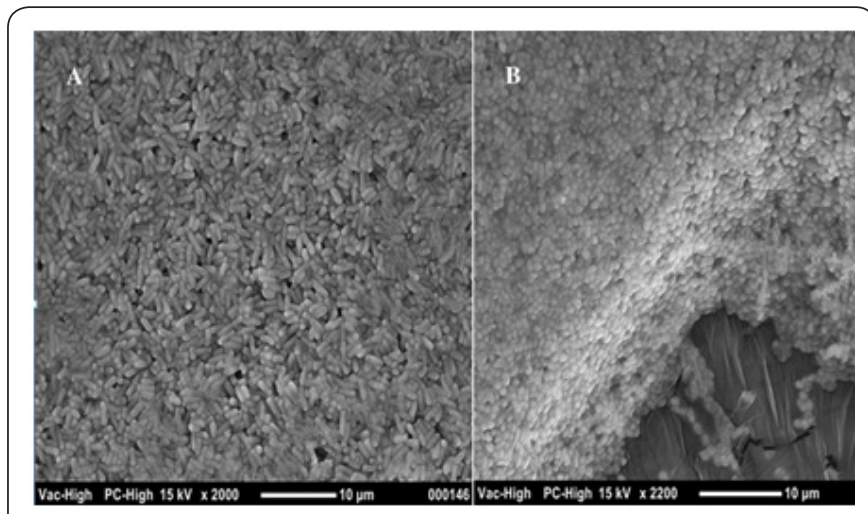

Figure 4.

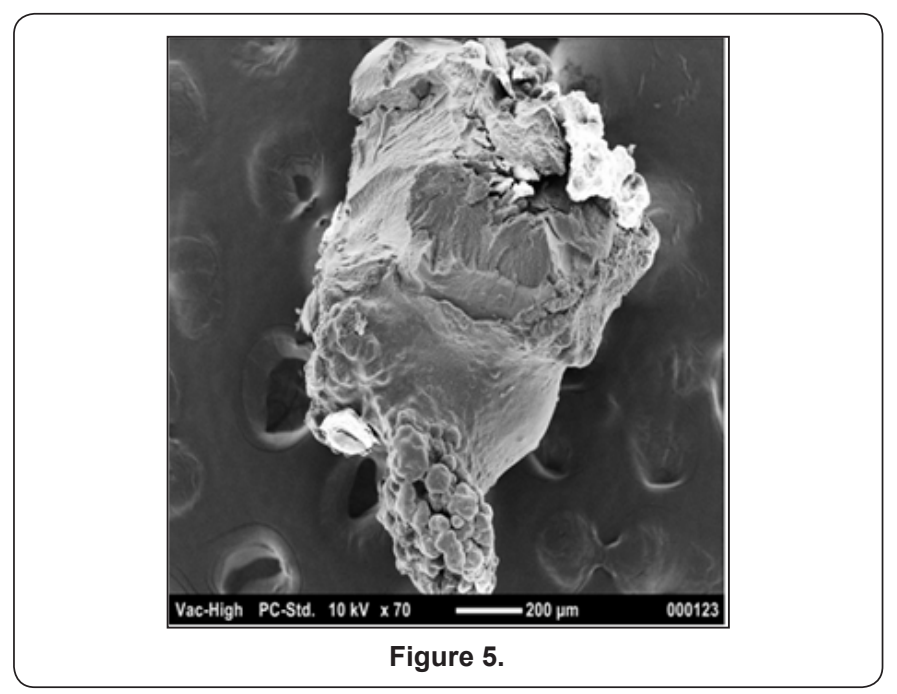

\section{K.G Naber et al. [17] showed that}

"Because of their unique and favorable pharmacokinetic properties and their broad antibacterial spectra, the fluoroquinolones are considered the agents of choice for the antimicrobial treatment of CBP. The duration of antimicrobial treatment is based on experience and expert opinion and is supported by many clinical studies [9]. In CBP an oral fluoroquinolone should be given for at least 4-6 weeks after the initial diagnosis. After treatment the patient should be reassessed periodically to determine appropriate treatment [3]. Relatively high doses are needed and oral therapy is preferred [10]. Treatment with intraprostatic injection of antimicrobials is not recommended as it is supported only by anecdotal reports $[11,12]$. In general, therapeutic results are good in CBP due to E. coli and other members of the family Enterobacteriaceae, but not in CBP due to P. aeruginosa and enterococci $[9,10]$.

\section{Prostatitis}

\section{J. Curtis Nickel, MD, FRCSC}

\section{Antimicrobial therapy (2:A)}

"Because of their unique and favourable pharmacokinetic properties, their broad antibacterial spectra and comparative clinical trial evidence, the fluoroquinolones are the recommended agents of choice for the antimicrobial treatment of CBP $[14,15,17]$. Data from CBP fluoroquinolone treatment trials with a follow-up of at least 6 months support the use of flouroquinolones as first-line therapy. The recommended 4- to 6-week duration of antimicrobial treatment is based on experience and expert opinion and is supported by many clinical studies [14,15,17]. In general, therapeutic results (defined as bacterial eradication) are good in CBP due to E. coli and other members of the family Enterobacteriaceae. CBP due to P. aeruginosa and Enterococci shows poorer response to antimicrobial therapy. CBP associated with a confirmed uropathogen that is resistant to the fluoroquinolones can be considered for treatment with trimethoprim-sulfamethoxazole (or other antimicrobials), but the treatment duration should be 8 to12 weeks.

\section{Alpha-Blockers (3:C)}

The combination of antimicrobials and alpha-blockers has been suggested to reduce the high recurrence rate 28 and this combination of two therapeutic regimens is considered optional for in-patients with obstructive voiding symptoms.

\section{Treatment Refractory Cases}

For treatment refractory patients with confirmed uropathogen localized to the prostate, the following are optional treatment strategies:

a) intermittent antimicrobial treatment of acute symptomatic episodes (cystitis) (3:A);

b) low-dose antimicrobial suppression (3:A); or

c) radical TURP or open prostatectomy if all other options have failed $(4: C) "[10]$.

\section{According Weidner W et al. [11]}

"Ciprofloxacin was used for the treatment of refractory chronic bacterial prostatis. 17 men with symptoms of prostatitis for more than one year who had not responded to treatment courses of six weeks trimethoprim-sulfamethoxazole or trimethoprim alone received $500 \mathrm{mg}$ ciprofloxacin twice daily per os for two weeks. Up to one year follow-up proved eradication of Escherichia coli in seven of ten and of other pathogens in two of five cases. In a second study, 16 patients with proven chronic bacterial prostatitis who had failed on pretreatment with cotrimoxazole, trimethoprim or norfloxacin, respectively, received $500 \mathrm{mg}$ ciprofloxacin twice daily for four weeks. E. coli was the causative organism for all cases. After a median follow-up of 30 (21-36) months, ten out of 16 patients are clinically cured 
with permanent eradication of the causative organism. In two men a second treatment course with ciprofloxacin is considered successful. Two patients stopped treatment for central nervous system complaints."[11].

\section{Perletti G et al. [12] writed that}

"Chronic bacterial prostatitis (CBP) is a persistent infection of the prostate characterized by poor quality of life mainly due to frequent relapse episodes caused by incomplete eradication of causative pathogens. Aggressive antibacterial therapy is required to attenuate the severe symptoms of CBP and to achieve a permanent cure. Although fluoroquinolones are currently recommended as first-choice agents, macrolide antibiotics are emerging as a noteworthy option for the treatment of CBP. Macrolide antibiotics are characterized by an impressive array of distinct pharmacokinetic (PK) and pharmacodynamic (PD) properties. These properties include high intracellular accumulation in phagocytes and at sites of infection, including the prostate; broad antibiotic but also biofilm-inhibiting properties; immunomodulating and inflammation-resolving activities. These features offer particular advantages for the treatment of chronic infections of the prostate gland [12].

\section{According Michael Dan et al. [13]}

"Our data suggest that Ciprofloxacin is a valuable Agent for the treatment of bacterial Prostatitis and related infections of the urinary tract." ( CIPRO 750 MG )[13].

\section{Lugg j et al. [14] Writed That}

"Infection is a potential complication of transrectal needle biopsy of the prostate (TRNBP), and antibiotic prophylaxis with a fluoroquinolone is commonly used. The objective of this study was to demonstrate penetration of ciprofloxacin into prostate tissue after administration of a ciprofloxacin $1000 \mathrm{mg}$ extendedrelease formulation prior to TRNBP.

The study enrolled 13 men aged 45-78 years scheduled for TRNBP. They received a single, $1000 \mathrm{mg}$, extended-release tablet of ciprofloxacin at about 3 hours or at about 1 hour prior to the scheduled biopsy time. Blood and urine samples were taken just prior to the biopsy procedure, and prostate tissue samples after all needle biopsy specimens required for diagnostic purposes had been obtained, for determination of ciprofloxacin concentrations.

Extended-release ciprofloxacin is well tolerated and penetrates effectively into prostate tissue. Tissue levels of ciprofloxacin are similar whether the extended-release ciprofloxacin is administered 1 hour or 3 hours before TRNBP, indicating that tissue levels are maintained for several hours after administration. PK modelling as used in this trial is suitable to prospectively outline clinical designs [14].

\section{Parnham MJ et al. [15]}

"Azithromycin is a macrolide antibiotic which inhibits bacterial protein synthesis, quorum-sensing and reduces the formation of biofilm. Accumulating effectively in cells, particularly phagocytes, it is delivered in high concentrations to sites of infection, as reflected in rapid plasma clearance and extensive tissue distribution. Azithromycin is indicated for respiratory, urogenital, dermal and other bacterial infections, and exerts immunomodulatory effects in chronic inflammatory disorders, including diffuse panbronchiolitis, post-transplant bronchiolitis and rosacea" [15].

\section{Conclusion}

\section{In General : According Biomedical Literature}

Responsible of relapses of chronic prostatitic and related relapses can be : biofilm, reduced urinary prostatic fluss in example by IPB , urinary reflux (chemical cystitis and prostatitis), prostatic cancer and other factors.

a. Biofilm is responsible about difficulties in diagnostic methods and in therapy.

b. Bacterical prostatities is associated in frequent E.Coli infectious, enterococcus faecalis but other germs

c. Can be involved (example clamidia, micoplasm).

d. Involved often Intestinal functional abnormalities and pathologies, ano-rectal, sexual transmission infectious and also due to bacterical sanctuaries and intraprostatic calcifications.

e. We have see that a bacterial disease can be primitive or secondary (bacteria cause of infection or sovrainfectious in a flogosis tissue or to other conditions) in example ipertonus in pelvic sfinteric muscle.

f. We have see the that infectious can be across different process: Trought ematogenic, lymphatic, contiguity, local pathology, sexual way, trans uretral UTI, GI pathologies, proctities, neoplasia, prostatic reflux, rectal bacteria linfatic diffusion and other.

g. Medical examination and Ecografy make possible to evaluate local situation in order to exclude other pathologies.

h. Ascessual evolution, micro litiasis and other tissue abnormalities.

i. Acute disease can develop in chornic evolution, with ascessual possibilities (needed surgical drainage) Only the Antimicrobial therapy efficacy only in little prostatic ascessual Cavity.

\section{Prostatic Ascess Contribute to Obstruction}

In other cases surgical drainage added to antimicrobial therapy is considered the gold-standard, hospitalization often required. Was reported Efficacy of synergic association of parenteral fosfomicin trometamol and NAC high dosage on Prostatic biofilm(E.Coli). (since $55 \%$ of action on biofilm, and $80 \%$ disgregation action). Also biocide activity is increased versus single drugs. Sequential therapy (FLUOROCHINOLONS 
and MACROLIES) gives more result on relapses related to The different antimicrobial spectrum and on biofilm (macrolides more active in last caharacteristics an macrophages penetration). (Fluorochinolons for 14- 28 days according the therapeutich scheme)

a. According literature Macrolides improve, by the biofilm activity, the toxicity of fluorochinolons versus bacteria.

b. Inside biofilm microbs can survive also to an antimicrobial concentration of 1500 times high vs normal dosage.

c. In patien with other relapses can be used other drugs as casrbenicillin, doxicillin, gentamicin, imipenem and other.

d. No responder patient are treated with low journal doses of antimicrobial (trimethoprim, nitrofurantoin, tetraciclin): BED THERAPY little antimicrobial doses for prolonged time (6 mouth- 1 year).

e. According a CLASSIC pharmacology book : "SMALL DOSES OF BACTRIM ARE EFFICACY TO PREVENT RECURRENT UTI AND BACTRIM IS EFFECTIVE FOR BACTERIAL PROSTATITIS “

f. In recurrent cistitis after sexual activities nitrofurantoina (50 mg) oppure norfloxacina (200 mg) or cephalexin $(250 \mathrm{mg})$ post coitus.

g. In article M. DAN was reported different intraprostatic concentration of ciprofloxacin after oral subministration in 15 patientvariable form 0,6 micrograms/gr to 4,18)and this show a variable tissue penetration. The same in this article was reported cases of high plasma concentration but related with reduced (1/2) intraprostatic ciprofloxacin concentration.

h. In literature was reported If batteriaemia or prostatic ascessual 3-4 week (drainage if $>10 \mathrm{~mm}$ ) and in chronic bacterial prostatitis : treat for 3-4 week if fluorochinolons germe and for 2-3 mounth if resistance germ to fluorochinolons with a macrolide (active on biofilm e on Chlamydia and related germs).

\section{Chronic Prostatitis : Some Therapies in Use}

a) Trimethoprim-Sulfametossazolo per os 80-400 mg x 2/ die;(33 - $40 \%$ eradications) 4-6 weeks

b) Ciprofloxacina $500 \mathrm{mg} \times 2$ /die o Ofloxacina $400 \mathrm{mg} \times 2$ / die 4 weeks (microbiological eradication $75 \%$ )

c) If Age $<35$ aa fluorochinolons (Clamydia and Neisseria Gonorrheae infectious) and in non reponder carbenicillin, la doxiciclin e la gentamicin.

d) Patient with not eradicated disease can take advantages using low daily dosage of antimicrobial prolonged time (tetraciclin, nitrofurantoin, trimethoprim)

e) Other scheme: see current therapy manuals

\section{Related this case report}

a) We can say that in all situation was not prescibed the right remedy vs biofilm? why was not prescribed IV ANTIMICRIOBIAL THERAPY using other molecule? antimicrobial molecules present the same relevance of antibiofilm products in this kind of situation?

b) Why in every specialistic consult was prescribed to this patient substantially the same therapy (for several years, and many specialist consulted hospital and out of this settings)?

c) This situation was underestimated?

d) Surely more must be introduced under the light of frequent relapse in some pathologic conditions like chronic bacteric prostatitis. (the same we can think about other situation involved in biofilm like protesis and medical devices infectious, heart valve pathology due by microbs and other endocarditis, fibrosisi cystic and other).

e) We think that under the light of systemic effect this kind of pathology must be treated under a right Approach (antimicrobials added to biofilm disgregations strategies).

f) Need we today novel delivery system to disgregate biofilm in order to make possible a right antimicrobial activity?

g) Can the clinical pharmacist help in the right decision making therapy systems adding specific Medicinal chemists competences to improve kinetics and dynamics in this situation.

h) Kinetics support the dynamics effect of drugs and an efficacy delivery strategies can improve the clinical effect.

\section{References}

1. Luisetto M, Nili-Ahmadabadi B (2017) Chronic Prostatitis: The Clinical Pharmacist Role and New Delivery Systems. J Bioanal Biomed 9: e151.

2. Mauro L (2017) Infectious Disease and Antimicrobial Agents the Best Way to Use a Limited Resource. Glob J Pharmaceu Sci 3(5): 555621.

3. Luisetto M (2017) Infectious Disease Pharmaceutical Care: The Role of the Clinical Pharmacists to Improve Clinical Outcomes. J Antimicrob Agents 3(2).

4. Luisetto M, Nili-Ahmadabadi B (2017) The Clinical Pharmacist Competence as Pharmaceutical Drug. Design Tool Research \& Reviews: Journal of Hospital and Clinical Pharmacy 3(2).

5. Vittorio Magri, Emanuele Montanari, Visnja Skerk, Alemka Markotic, Emanuela Marras, et al. (2011) Fluoroquinolone-macrolide combination therapy for chronic bacterial prostatitis: retrospective analysis of pathogen eradication rates, inflammatory findings and sexual dysfunction. Asian J Androl 13(6): 819-827.

6. Takeshi Mikuniya, Yoshihisa Kato, Takashi Ida, Kazunori Maebashi, Reiko Kariyama, et al. (2007) Treatment of Pseudomonas aeruginosa biofilms with a combination of fluoroquinolones and fosfomycin in a rat urinary tract infection model. Morooka-Cho 760, Kohoku-ku, Yokohama 222-8567.

7. Cristina Delcaru, Ionela Alexandru, Paulina Podgoreanu, Mirela Grosu, Elisabeth Stavropoulos, (2016) Microbial Biofilms in Urinary Tract 
Infections and Prostatitis: Etiology, Pathogenicity, and Combating strategies. Pathogens 5(4): 65.

8. Bjerklund Johansen TE, Grüneberg RN, Guibert J, Hofstetter A, Lobel B, et al. (1998) The role of antibiotics in the treatment of chronic prostatitis: a consensus statement. Eur Urol 34(6): 457-466.

9. K G Naber (2003) Antimicrobial Treatment of Bacterial Prostatitis. Department of Urology, Hospital St Elisabeth Str 23, 94315 Straubing, Germany PlumX Metrics.

10. J Curtis Nickel (2011) Prostatitis: FRCSCAntimicrobial therapy. Can Urol Assoc 5(5): 306-315.

11. Weidner W, Schiefer HG (1991) Chronic bacterial prostatitis: therapeutic experience with ciprofloxacin. Infection 19 Suppl 3: S165-S166.

12. Perletti G, Skerk V, Magri V, Markotic A, Mazzoli S, et al. (2011) Macrolides for the treatment of chronic bacterial prostatitis: an effective application of their unique pharmacokinetic and pharmacodynamic profile 4(6): 1035-1044.

13. M Dan, J Golomb, A Gorea, Z Braf, S A Berger (1986) American Society for Microbiology Concentration of Ciprofloxacin in Human Prostatic
Tissue after Oral AdministrationMICHAEL DAN, Antimicrobial Agents and Chemotherapy.

14. Lugg J, Lettieri J, Stass H, Agarwal VJ Chemother (2008) Determination of the concentration of ciprofloxacin in prostate tissue following administration of a single, $1000 \mathrm{mg}$, extended-release dose 20(2): 213-218.

15. Parnham MJ, Erakovic Haber V, Giamarellos-Bourboulis EJ, Perletti G, Verleden GM, et al. (2014). Azithromycin: mechanisms of action and their relevance for clinical applications. Pharmacol Ther 143(2): 225245.

16. Magri V, Montanari E, Škerk V, Markotić A, Marras E, et al. (2011) Fluoroquinolone-macrolide combination therapy for chronic bacterial prostatitis: retrospective analysis of pathogen eradication rates, inflammatory findings and sexual dysfunction. Asian J Androl 13(6): 819-827.

17. Wagenlehner FM, Naber KG (2003) Antibiotic treatment for urinary tract infections: pharmacokinetic/pharmacodynamic principles. Expert Rev Anti Infect Ther 1: 275-282.

Your next submission with Juniper Publishers
will reach you the below assets
- Quality Editorial service
- Swift Peer Review
- Reprints availability
- E-prints Service
- Manuscript Podcast for convenient understanding
- Global attainment for your research
- Manuscript accessibility in different formats
( Pdf, E-pub, Full Text, Audio)
- Unceasing customer service
Track the below URL for one-step submission
https://juniperpublishers.com/online-submission.php

